\title{
GraSsLANDS ABLAZE: VegetaTion BURNING BY RURAL People in Pondoland, South Africa
}

\author{
T.KEPE
}

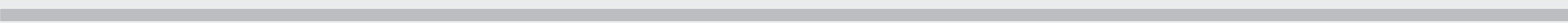

\section{ABSTRACT}

Despite decades of anti-fire rhetoric and different legislation regulating the use of fire, poor rural people in South Africa continue to burn vegetation outside of the recommended periods. This paper explores some of the possible reasons for this 'uncontrolled burning' by rural people. Using a village case study from Pondoland, the paper argues that people's defense of their livelihoods is a key reason; whether this be through using fire to manage natural resources or as a form of protest against those they perceive to be powerful. Thus, detailed understanding of the nature of livelihoods, the history and struggles of the people concerned, as well as local institutional landscape is crucial. Environmental degradation, whether by fire or other things, therefore, is not an ecological issue alone, it is as deep as the people's histories, economic and political situation and, therefore, has to be dealt with and understood in that context.
\end{abstract}

\section{Introduction}

African savannahs and grasslands have been subjected to burning by residents and other users for several centuries (Botha, 1924; Booysen and Tainton, 1984; Bucini and Lambin, 2002; Laris, 2002). In South Africa, despite extensive research, mostly throughout the $20^{\text {th }}$ century, on the negative and positive impacts of fire on different vegetation, much confusion and disagreements still remain on what fire-related policies should be implemented. Part of this confusion and disagreements could be the result of the dualistic land use and production systems between blacks and whites, the poor and the wealthy and subsistence and commercial agriculture, still evident in South Africa today. Throughout the twentieth century, legislation and rhetoric criminalized or discouraged vegetation burning by black and poor land users who lived in the Bantustans ${ }^{1}$ (see Cooper, 1991; Van Wyk, 1994; Barlow and Buchan, 1995). On the other hand, in addition to the fact that past and current experiments on the advantages and disadvantages of vegetation burning are mostly being conducted on white-owned commercial farms or research stations and nature reserves that mimic commercial production systems (see Botha, 1924; Marloth, 1924; Venter, 1968; Booysen and Tainton, 1984; Bijker, et al., 2001; Wiseman et al, 2002) it can be argued that earlier and current fire legislation is primarily designed for commercial and private holding situations. These include the Forestry Act (No.72 of 1968), Soil Conservation Act (No.76 of 1969) and the current National Veld and Forest Fire Act (No.101, 1998). For example, the National Veld and Forest Act (No.101 of 1998), proposes the establishment of fire protection associations, who are entitled to financial assistance from government, and who are also to receive fire danger warnings from government, through three television channels, three radio stations and two newspaper notices ${ }^{2}$ (also see Booysen and Tainton, 1984:359 for the earlier Acts). With extreme poverty and absence of various infrastructures, which make it difficult to gain access to information, among other things, it becomes clear that rural people living in communal areas are not fully accommodated in such legislation.

However, in the midst of these irregularities in terms of formulation and implementation of the legislation, there was never a doubt that vegetation burning in the Bantustans was regarded as ecologically detrimental ${ }^{3}$ by the state and conservation activists (Barlow and Buchan, 1995; Cooper, 1991; Van Wyk, 1994). It can also be argued that anti-burning rhetoric by the state and environmental protection activists often accompanied by ambiguous and inconsistent implementation of anti-fire sanctions by individual agents (see also Kull, 2002) -, rather than legislation, appears to be what has impacted on past and current fire management practices in the former Bantustans. During the homeland era in the former Transkei for example, extension officers discouraged villagers from burning vegetation under any circumstances. To this day, in some "Transkeian" villages, people are forbidden from burning any form of vegetation without getting permission from the headman.

In spite of all the legislation, rhetoric, intimidation and confusion, poor rural people in South African former Bantustans continue to burn vegetation on regular basis. The persistence of this act, among other things, makes natural resource management a highly conflict-ridden issue at various levels, including amongst villagers themselves, between them and those in positions of authority (e.g. headmen, government officers) and between policy researchers and other commentators who hold divergent views.

Using a case study of Pondoland, in the Eastern Cape Province, this paper aims to complement other studies, which are often technical and ecological, by adding the socioeconomic dimensions to understanding vegetation burning in areas occupied by poor rural people living under communal arrangements. The paper suggests that there are possibly four key reasons why the rural poor continue to burn vegetation the way they currently do, in the face of suspicion and opposition from outsiders. The first reason is likely to do with their livelihood needs and the challenges they face in achieving these. The second reason could relate to the way they manage their relationship with and respond to the opponents of vegetation burning by the rural poor. The third reason is possibly the existing inconsistencies in relation to the implementation of fire legislation by the state, as well as the uneven and often biased rhetoric by nature conservation activists. The fourth reason is likely to do with the state of local natural resource management institutions, including those that are supposed to mediate burning.

The paper is based on long-term fieldwork in Eastern Pondoland between April 1996 and June 2003. A variety of methods were used to collect information used in this paper. Primarily, the study employed ethnography, which involved a nine-month full-time residence in Khanyayo village in 1996. Participant observation, semi-structured interviews, ecological site histories, air photo analysis and a range of participatory rural appraisal (PRA) techniques were used. The PRA techniques used included village resource mapping, transect walks and seasonal calendars with villagers, to learn about the different sites in the rangeland, as well as times when certain activities took place. Secondary data, including archival material, legislation and policy documents were also used. 
Following this introduction, the next section briefly contextualizes vegetation burning within the global environmental degradation narratives. This is followed by a detailed case study of a village in Pondoland, which discusses rural people's reasons for burning and their responses to opposition by outsiders. The last section of the paper presents discussion and conclusions for research and policy with regard to natural resource management and rural livelihoods in South Africa.

\section{Narratives and political ecology of environmental degradation}

\section{Narratives}

A set of powerful, widely held beliefs about the causes of environmental degradation in many African countries are the driving force behind those countries' environmental policies. Overuse of natural resources, overgrazing, poor agricultural practices and "uncontrolled" burning by the rural poor, are often seen as the main culprits. Simply put, poverty is seen as the greatest threat to biodiversity and biological sustainability (see for example Mabogunje, 2002; Sanderson and Redford, 2003). So believed and accepted is this formula amongst policy makers and practitioners in African countries, as well as to some international agencies, that it has acquired the status of conventional wisdom (Leach and Mearns, 1996). Conventional wisdom about environment and poverty linkages are often presented in the form of narratives. In an influential article published in the journal World Development, Roe (1991) defines a narrative as a story, with a beginning, middle, and an end, which is cast in the form of an argument, and is set around a sequence of events in which something follows. Narratives do not describe what should happen, but what will happen if certain things are done. The main objective of these narratives is to spur those who hear them into believing the story or acting against the problem. However, research has now shown that many of the narratives relating to poverty and the environment in Africa, have neither benefited the rural poor nor the environment that they sought to safeguard (Tiffen et al., 1994;Fairhead and Leach, 1996; Leach and Mearns, 1996; Scoones, 1996).

South Africa is a good example of a country whose environmental policies are heavily influenced by powerful narratives relating to poverty and environment. One such narrative states that "uncontrolled" burning by people living in South Africa's Bantustans leads to environmental degradation (for example see Van Wyk, 1994; Cooper, 1991; Barlow and Buchan, 1995). The rural poor are thus constantly on the receiving end of anti-burning rhetoric from different levels of authoritative structures. It is therefore interesting to try and understand how this practice manages to survive. I suggest that the political ecology approach encourages a systematic way of exploring this question.

\section{Political ecology}

Human-environment relations, which include the impact of burning on the natural environment, have been researched the world over. Yet many of such studies continue to uncritically accept conventional explanations of environmental degradation, without fully appreciating the social and political constructions of such relationships (Batterbury et al., 1997). As poverty endures in some parts of the world, and environmental problems increase, there is a need for an analytic approach that integrates environmental and political understanding. The emergence of the field of political ecology in the early 1970s was primarily a response to this need (Bryant and Bailey, 1997; Benjaminsen and Derman, 2003).

The political ecology approach is seen as the integration of the ecological, social and political concerns. Hershkovitz
(1993) distinguishes between two ways in which the term political ecology is used in the academic discourse. On the one hand, it is seen as the politicization of environmental concerns. In this sense, political ecology is both a way for understanding environmental issues politically, and a programme for change in the social and political landscapes. On the other hand, political ecology is seen as focusing on micro-level analysis of people-environment relationships and resource use in diverse settings, but mostly in poor countries. In this sense, it seeks to understand the position of communities within the broader global economy. According to Hershkovitz (1993), political ecology is behavioural in its emphasis, in that it asks questions about why land and natural resource users do certain things that in many cases exacerbate physical processes that in the long-run undermine their own livelihoods. Even though these questions are situated at the individual or household level, the answers are often located at higher and broader political economy level (Blaikie, 1985; Hershkovitz, 1993).

\section{Location}

\section{Pondoland case study}

The case study area, Khanyayo (See Figure 1), is situated in north-eastern Pondoland $\left(31^{\circ} 13^{\prime}-31^{\circ} 20^{\prime} \mathrm{S}\right.$ and $\left.29^{\circ} 55^{\prime}-30^{\circ} 4^{\prime} \mathrm{E}\right)$, between two rivers, Mtentu and Msikaba, in the Wild Coast. The area is inhabited by the Khanyayo people who speak a Xhosa dialect (IsiMpondo). I begin by presenting a brief history of Pondoland, as well as a general description of the biophysical context of the part of the Wild Coast area falling within Eastern Pondoland. That discussion is followed by a discussion of the dynamics of use of fire in the village.

\section{Historical background of Pondoland}

Pondoland lies between the uMtata River to the south, and uMtamvuna River to the north. Eastern and Western Pondoland are separated by the uMzimvubu River. In 1894, Pondoland was the last southern Africa state to fall under colonial rule. Even after annexation, the impact of conquering was felt less in this area than in the neighbouring states (Beinart, 1982). Three reasons are suggested for this minimal impact of colonialism on the life of the Mpondo. Firstly, while the Mpondo occupied land that was almost in the middle of two colonial strongholds of Natal and the Cape Colony, the land bordering on both these areas was occupied by Africans, who absorbed the worst effects of direct confrontation with colonial powers, and thus lessening the impact on Pondoland (Beinart, 1982). Secondly, the legacy of Faku - the Mpondo king from roughly 1818 to 1867 - played an important role in minimizing the impact of colonization in Pondoland. It is said that Faku adopted a strategy of not (aggressively) resisting European influence, which probably saved his land and position (Beinart, 1982; Stapleton, 2001). This he did by allowing traders to

Figure 1: Map of the case study area

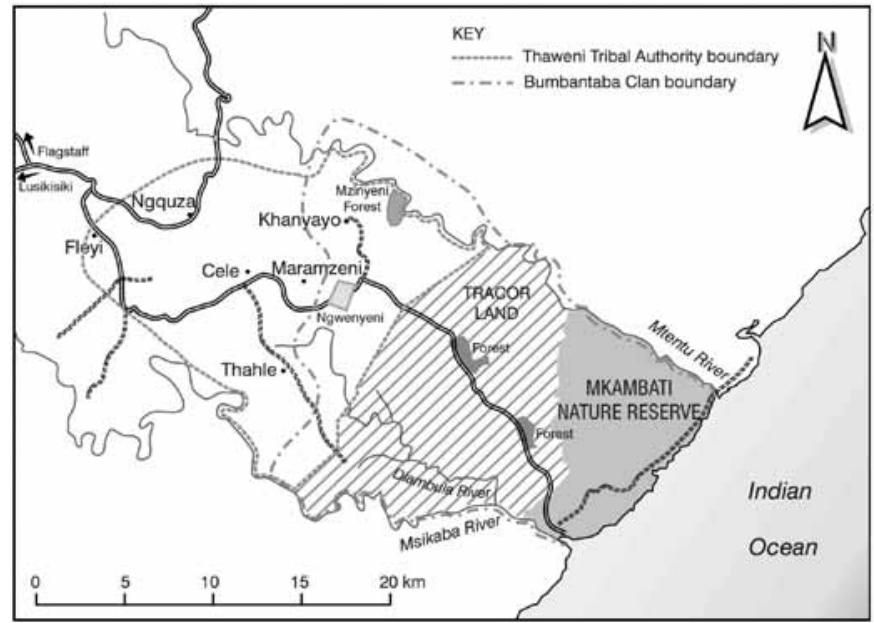


barter with his people, and in 1830 permitted a Wesleyan missionary station to be established within his kingdom. Stapleton (2001) argues that the missionaries further served as the main channel of communication between the Mpondos and the Cape Colony, and later Natal. Thirdly, Stapleton (2001) contends that Faku's militancy, which saw him provide protection to smaller chiefdoms who were fleeing from Shaka raids in Zululand, and who brought along with them large numbers of cattle, as well as the fact that Mpondos had adopted many agricultural innovations, ensured that the kingdom's economy remained vibrant. Consequently, the Mpondo were at first unlike other annexed neighbouring nations - not forced to be totally dependent on what the colonizers offered. They were able to maintain a certain level of economic independence. However, two major cattle-killing diseases (Rinderpest in 1897 and East coast Fever between 1912 and 1913), dealt a blow to their economy by killing most of their cattle. This forced the Mpondos into labour migrancy. By the end of the twentieth century, labour migrancy, cattle and agriculture were still very important to the Mpondos (Kuckertz, 1990; Beinart, 1992; Kepe, 2001).

While the Mpondos were not totally opposed to the opportunities that came with colonization, they were always deeply concerned about the threats that government intervention, would have on their patterns of land occupation and use. Consequently, on numerous occasions during the late 1800s and throughout the twentieth century, ordinary people had conflicts with their traditional authorities, blaming them for selling Mpondo land and people for their own benefit. One of these occasions came in late 1950s and early 1960s, when chief Botha Sigcawu agreed to the Bantu Authorities and rehabilitation schemes. On this occasion, peoples' dissatisfaction was expressed through violence, in what became the famous Pondo Revolts. The Pondo Revolts represented the fiercest opposition to environmental rehabilitation. The rehabilitation scheme, commonly known as Betterment Planning, was forcibly introduced by the state as a measure for combating the deterioration of rural environment, by dividing land in a locality into residential, arable and grazing sections, throughout the country (see Mbeki 1984; De Wet, 1995). Reasons for rejecting Betterment ranged from the alleged restrictions it imposed on the movement of livestock, to reduction of grazing areas and cropping land. Coastal districts of Lusikisiki and Bizana showed the most resistance against betterment (Mbeki, 1984; Copelyn, 1974). Government did all in their power to crush the revolts. On June 06 1960, unarmed Mpondo peasants were massacred by government troops at Ngquza Hill, near Flagstaff. On that day many rebels were killed and hundreds were arrested.

The Pondo Revolts, which were one of the most intense political uprisings in rural South Africa during the twentieth century, showed, clearly, the extent to which the rural poor are prepared to go in defending their livelihood. Historically, land, trees, grazing resources and numerous other natural resources have been important part of Mpondo peoples' livelihoods (Hunter, 1979; Beinart, 1982; 2002). Thus, new laws governing land occupation, forests, grazing, burning and livestock movement have, historically, been seen by rural people as a threat to their livelihoods, and vigorously resisted where possible. During the last few decades of the twentieth century, resistance against regulations governing natural resources that are important in livelihoods took different forms, which combined violent and non-violent means (Kepe, 2001). However, through oral history, new generations are made aware of the suffering that the Mpondos have endured in the hands of colonial and apartheid governments, and how any resistance to defend a livelihood is a just cause. It has also emerged over time that defense and resistance for the sake of livelihoods has little regard for tradition and hierarchy (Hunter, 1979; Beinart, 1982).

\section{Biophysical description}

The Wild Coast area, part of which is the case study area, covers a coastline area of about 300 kilometers between the Great Kei River to the south and uMtamvuna River to the north. Being part of the former Transkei Bantustan, which since 1994 has been re-incorporated within the Eastern Cape Province, the area is characterized by poorly developed infrastructure and acute poverty. Ironically the Wild Coast has, since the late nineteenth century, been widely recognized as an area of great natural beauty and is often regarded as "unspoilt" (Schmidt and Doonan, 1997) or "undisturbed". Its primary attractive features are its rare vegetation, including many endemic species, as well as its rugged, rocky shores with violent waves reaching heights of as much as ten metres.

The case study area is dominated by poor soils of sandstone origin, with patches of rich clay soils of dwyka origins as one moves further away from the coast (Feely, 1987). The area receives over $1000 \mathrm{~mm}$ of rainfall per annum, with a rainfall peak in the summer, although with substantial winter rainfall due to the effects of sea fog and mist. The area is dominated by grasslands, which make up as much as 80 percent of the coastal vegetation, with subtropical forests patches found along the gorges and the ravines or along the dune systems by the coast. Some commentators regard these grasslands to be secondary, with the forest patches being relics of a former extensive forest (Acocks, 1953; Cooper, 1991). However, such a view has been disputed by others (Feely, 1987; Ellery and Mentis, 1992), who refer to extensive archaeological information, showing that the coastal grasslands have been in existence for several thousand years. Other supporting evidence against the anthropogenic origin of these coastal grasslands comes from early accounts of people who visited the area. For example the description of the landscape given by Perestrello (1554), a shipwreck survivor who trekked across the area in 1554 highlights the prominence of grassland vegetation rather than forest. Much later, a variety of other travelers passing through the coast of Eastern Pondoland commented on the grasslands and their use. For example, Sampson, in 1882 commented on what he saw in the vicinity:

Before us, and as far as the eye could see, lay a vast panorama of undulating grassland, delicately wreathed with low lying mist and dotted irregularly with dark patches of forest (Sampson, 1882:105).

The communal areas are dominated by an extensive, poor quality, Aristida junciformis (Inkonkoni in isiXhosa) grassland. Along with grasslands scientists, farmers in the area recognize that Aristida is undesirable. However, following the standard recommendation of light grazing and seasonal burning to retain more palatable grass species is not feasible under the current conditions of intensive land pressure and high stocking rates. In order to cope, the users of these grasslands, through several processes (e.g. burning, seeding, fire protection, soil enrichment etc), are able to create and manage a diversity of patches, to suit diverse needs (Kepe and Scoones, 1999).

\section{The defense of livelihoods through burning}

In this paper, livelihoods are understood as assemblages or structures of activities through which people (individuals or groups) attempt to make a living. These include assets (both material and social resources) and capabilities, and are mediated by economic, political and institutional contexts (Chambers and Conway, 1992; Slater, 2001). Two important features of livelihoods, which this paper emphasizes, are that they are diverse and complex. This diversity and complexity extends to the rights and claims to natural resources that people make use of in securing those livelihoods, as well as to how resources are managed for each of several livelihood-related goals. 
Given a mean annual rainfall of more than $1000 \mathrm{~mm}$, which occurs throughout the Wild Coast, rain-fed crop production in Khanyayo is not limited. In spite of the shallow soils in the coastward sections of the village, cropping is one of the most important, though not major, livelihood activities in local households. Fields or gardens of between one and two hectares are located near respective homesteads. The planting season begins in September, while harvesting takes place between May and July. Maize (umbona) is by far the most popular crop, followed by taro (amadumbe), pumpkin (ithanga or impuzi) and sweet potato (ubhatata). As for livestock, cattle are the most popular. Long-term research in this area reveals that over 50 percent of the households keep cattle, either as owners or through loaning arrangements (Kepe, 2002). Additionally, eastern Pondoland, within which Khanyayo falls, has long been recognized for its relative suitability for cattle production within the former Transkei (formerly Transkeian Territories). In the late $19^{\text {th }}$ century, for example, Sampson (1882:105) wrote of the area during one of his visits to Lusikisiki area:

I had seen the natives of Mount Frere almost frantic at the sight of two or three thousand head of captured cattle, but here, in light and shade of the green hills, was to be appreciated the true beauty of the many herds. No wonder with their pleasant land, luxuriant crops, and multitudinous cattle, the Pondos are content to abide in the paths of peace...

Later, Caesar Henkel (1903:46), when he wrote of Mpondo cattle, made similar observation:

Pondoland, of all parts of the territories, is 'par excellence' the cattle breeder's paradise. Before the advent of the 'Rinderpest plague' enormous herds of fine large and healthy cattle could be seen in East and West Pondoland.

With this background of cattle-keeping in the area, it makes sense that rangeland management, including through the use of fire, is crucial in local livelihoods.

Contributions made by livestock and crop production are by no means the only important ones in local livelihoods. Local residents generate their livelihoods through a mixture of arable and livestock farming, the collection of a range of natural resources, and a range of off-farm sources, including remittances and pensions. Vegetation burning practices are, therefore, mostly intertwined with these complex livelihood systems. In addition to accidental fires, such as those initiated by smokers, honey collectors and children, rural people in Pondoland burn to manage natural resources, as well as a form of protest. These are discussed below.

\section{Fire as a resource management tool}

In general, burning to manage natural resources to meet certain livelihood goals is perhaps the most common use of fire in rural Africa (Kull, 2002; Laris, 2002; Bucini and Lambin, 2002). In the case study area there are at least five broad reasons why people use fire as a natural resource management tool. Firstly, given the fact that almost $80 \%$ of the local vegetation is grassland, and that most of these are made up of the unpalatable Aristida junciformis grass species, villagers see the need to burn on regular basis. A combination of the fact that once present in the rangeland, Aristida junciformis is very difficult to eradicate (Kepe and Scoones, 1999; Wiseman et al, 2002), and that cattle are important to local livelihoods (Kepe, 2002), local villagers argue that the most sensible option available to them is to fire the grasslands throughout the year to maintain a young, palatable sward of this grass. Villagers are aware that this action exacerbates the problem of Aristida dominance, but argue that in the absence of other alternative management options or livelihood strategies, they are forced to carry on burning. The maintenance of a young grass sward through burning is, however, not limited to Aristida junciformis. Hunters from villages adjacent to Mkambati Nature Reserve (See figure 1) burn grass strips along the inside boundaries of the reserve, in order to attract wild herbivores to the new grass in edges of the reserve, where they become easy targets for the hunters.

Secondly, burning is used to create firebreaks around key sites and resources. Throughout the year, but mostly during late spring and early summer, villagers burn around their homesteads to protect themselves from runaway fires initiated by their neighbours, who, ironically, are also burning in fear of runaway fires from firebreaks being created by others. While it is not the primary reason, households who keep sheep and horses argue that the young sward from the burnt area around the homesteads becomes useful for livestock that is often not herded out far away from the homesteads. The second most popular use of firebreaks is to protect key resources such as the locally important thatch grass Cymbopogon validus, privately owned forest patches and grave sites. In the case of thatch grass and forest patches, if a villager is the first one to create a firebreak around such a resource growing on common property, they become de facto owners of that resource, by virtue of having invested in managing it.

Thirdly, local villagers burn grass to eradicate ticks. The most common tick that villagers seek to eradicate is the Blue tick (Boophilus decoloratus). Those who burn for controlling ticks do so during the winter months (June to August) before the young ticks attach themselves on to the hosts (livestock). There are also reports that people burn paths to drive away snakes. Fourthly, fire is used for clearing land for either cultivation or building houses. While others argue that fire has negative impact on soil and vegetation (see Marloth, 1924; Russell, 2003), local villagers believe that the ash that remains after the fire is good for enriching the soil. Lastly, local respondents tell of cases where desperate women burn woodlands, in order to speed up the drying process in the wood they wish to collect for fuel in future. While this is not a very common practice, it is a clearly planned resource management strategy.

It is important to note that these different reasons for the use of fire in resource management are not mutually exclusive. While people can clearly distinguish these different reasons when they burn, they are also aware that burning for one reason can also cover other purposes. For example, a firebreak around a homestead is also a way of maintaining a young grass sward for grazing by livestock. However, this non-mutually exclusive nature of burning can also have negative, unintended consequences, which could even lead to conflicts amongst villagers. For example, the burning of grass by men, mostly to maintain immature Aristida or to eradicate ticks, also means that there is less grass available for women to use for thatching purposes. Due to the scarcity of the locally favoured Cymbopogon validus (Shackleton, 1990; Kepe, 2001), the notional value of Aristida junciformis as a thatch grass has increased over the last two decades. It therefore makes sense that the majority of people who create firebreaks around thatch grass patches are women, in an attempt to defend a livelihood source, as thatch has value for both domestic use and for trading purposes. With these potential conflicts, burning actions that are in response to what others do (e.g. firebreaks), and the fact that fire is often initiated by individuals who have their own, often quite different, livelihood needs at different times, successful implementation of the current fire legislation in areas like Pondoland appears unlikely. While fire is regarded as extremely dangerous (Marloth, 1924; Botha, 1924), local 
users continue to see it is one of the most powerful weapons with which they can defend their livelihoods against nature and other people.

\section{Fire as a weapon of resistance}

Use of fire to defend a livelihood is not only confined to its use to manage natural resources. In addition to being used during wars between nations over many centuries, fire has now become a tool used by powerless individuals or groups against those they perceive to be powerful (Scott, 1985; Kuhlken, 1999; Kull, 2002). In the case study area there are at least two levels in which fire as a weapon of resistance is used. The first one is between individuals or groups in the village, and the second one is between the village individuals or groups and outsiders, particularly the state. In the first instance, resource conflicts between two parties, where there is a perceived power imbalance, and hence one party feeling victimized, fire becomes one of the few options available to settle the dispute. In Khanyayo for example, it is reported that disputes between women, over thatch grass and forest patches, that are mostly mediated by the local headman or neighbourhood men, often result in one of the two parties in the dispute feeling disadvantaged. In other words one of the women may complain that she would never get a fair trial because her opponent is either related to the chief or to a particular man who is responsible for mediation. If the woman who feels this way indeed loses the case, it is reported, the next thing that is observed is the torching of the resource in question by an "unknown" person. While not necessarily related to a resource conflict, revenge over some unrelated conflict between villagers is also often followed by the burning of some property belonging to one of the feuding parties.

In the second instance, villagers occasionally use fire to show their disapproval of an externally imposed regulation. For example in recent years villagers of Khanyayo have used fire to aid them in their fight for resource rights on neighbouring land that is currently occupied by the state, but which they believe is rightfully theirs. Over the last 10 years several fires have been started on the TRACOR state farm and Mkambati Nature Reserve (See figure 1). The Khanyayo were forcibly removed from both areas in 1920, to make way for a leper health institution. Since then, in spite of the promises made by the state through the land reform programme, villagers have been unsuccessfully pushing to regain their rights to these lands (Kepe, 2001). While no single person or group has overtly admitted to setting fire on the vegetation found in these two areas, comments such as "if we can't have it, nobody will" and "the fire is to provoke the person who believes that this land is theirs, to come to us and ask "who is burning my land?'" are often heard. Such defiance through the burning of vegetation is, however, not new in Pondoland. Barlow and Buchan (1995:102) make following comment for the period around the middle of the $20^{\text {th }}$ century:

Headmen also encouraged the burning of the veld and many of them ordered their people to burn the grass. No matter how often it was pointed out to them that burning the grass in the winter months would only cause sour veld, the headmen still persisted in this pernicious habit. This was why so many people referred to Pondoland as a "green desert".

While it is unclear from this account whether the case of headmen encouraging people to disobey the state was prevalent, one would have to assume that with or without their tacit blessing, or encouragement, people would have burnt the grasslands as a way of protest. Historically, Mpondo people have shown that any form of resistance against the state is justifiable if it is to maintain their way of life or to defend their livelihoods (See Beinart 1982; Mbeki, 1984; Beinart and Bundy, 1987).

\section{Discussion and conclusion}

What has emerged thus far in this paper is that vegetation burning has, for a long time, been and continues to be a central feature of rural livelihoods in Pondoland. Whether it is used to manage resources or to defend livelihood sources or a way of life, fire in Pondoland or any area that has similarities, is motivated by at least two things. Firstly, according to Briers et al (1996), presumably because of climate and edaphic factors, grasslands of coastal Pondoland are dense and particularly vigorous, permitting a high burning frequency. In other words, if it were in the nature of these grasslands to require frequent burns, one would have to assume that land based livelihoods would be somewhat disrupted if people did not burn as frequent as needed. While Van Wyk (1994) agrees that these grasslands are dense and vigorous, and thus need fire, he believes that local land users are over-using fire and that this is detrimental to the vegetation. Secondly, also related to livelihoods, the nature of rural poverty, which can be partly blamed on the previous and current governments, are somewhat responsible for the types of livelihoods, which necessitate the excessive use of fire currently experienced. In other words, therefore, the root cause of "excessive burning" in for the sake of local livelihoods, often has to do with factors that local people have little control over.

Another possible reason why "uncontrolled burning" persists in Pondoland is the manner in which Mpondo people have historically responded to confrontation. For example, in the case study area people justify their actions of resource theft from "state land" or breaking of a regulation while engaging in a livelihood activity, by calling on customary rights, locally referred to as ukujola (legitimized "illegal act"), which are based on historical claims predating current legislation. In terms of this notion, frequent burning of vegetation or theft from the nature reserve do not constitute a crime, because there is general understanding from local people that they are not breaking any law, so long as it is to derive a livelihood. This notion is not new in Pondoland. Early literature on the life of the Mpondos before and after annexation refer to this concept: For example, Callaway (undated: 69) quotes Bishop Key who wrote of the Mpondos a few years prior to the 1894 annexation:

At one time theft was unknown in Pondoland. A Native has been known to follow a trader's wagon for miles for the purpose of restoring a handkerchief which had been dropped. But the resistance offered to the extradition of thieves has had a very bad effect on the people....Protection has been shown to thieves from other tribes who have run into Pondoland with their spoil. This has been done simply, they will tell you, by way of retaliation. They consider that they have been badly treated, and, being the weaker party, they have used these means of repaying themselves by a system of passive resistance...

It is partly due to this passive resistance that "uncontrolled" burning has persisted in the face of a century-long campaign by the state and nature conservation activists, to discourage it. Villagers argue that confrontation, even if they know that they are not doing anything wrong, is not beneficial to them if it could result in some form of punishment (e.g. a jail term). Hence even in the case of use of fire to settle local resource conflicts, some "unknown" person is often the culprit.

The third possible reason that "excessive" burning has continued to this day, is that the tone in which opponents of vegetation burning by poor people deliver their message is often biased and at times not even based on extensive and convincing evidence (Leach and Mearns, 1996). This perceived bias is possibly responsible for the emergence of a new breed of researchers, who have committed themselves to reversing 
this trend and are therefore proposing alternative views. Some of these alternative views do manage to make their way into environmental policies or academic programmes in poor countries. Therefore, some previously rigid and inconsistent legislation may end up being implemented by sympathizers of local activities.

Exacerbating the poor effectiveness of state policies in rural areas of South Africa is the fact that rural people are often unaware of new legislation or guidelines, as these are often published in government gazettes, urban newspapers specialized magazines and newsletters (e.g. Farmer's Weekly), television and, to a smaller extent, through radio. Government agents, if they are visible in the rural areas, and non-government organization employees working with the local people, are often the only channels for communicating government policies and legislation to rural people. If these agents choose not to, or do not communicate these accurately - whether deliberate or not - rural people will remain in the dark about how the state expects them to manage the resources at their disposal.

Lastly, much closer to home, is the possibility that the state of the local natural resource management institutions a direct effect on how, why, where and by whom is burning carried out. According to local history, almost 30 years ago burning used to be controlled within the village area by collective management at the neighbourhood level, coordinated by the local headman and village elders. Rules and sanctions relating to burning were established and enforced by the traditional authorities. However, local people point to a number of factors, which may have acted together to change the local institutional matrix. First, population increase in the area over the last few decades may have resulted in increased competition for good grazing, which might have triggered individualistic strategies. This may mean earlier burning on a favoured patch, giving the grass no opportunity to recover. Second, shortage of herding labour, compounded by boys and girls attending school in greater numbers than before, and the infirmities and deaths caused by HIV-Aids and other diseases, more and more people tend to burn closer to home on regular basis - and often without negotiating with others - in order to keep their livestock closer to home. Third, the increasing tension and uncertainty with regards to the powers and functions of elected local government and traditional authorities, has resulted in a power vacuum in many former Bantustans (Maloka, 1996; Ntsebeza, 1999). This is exacerbated by the rise of civic organizations in rural areas that, to some extent, captured the political space that results from the feud and confusion between the elected local government structures and traditional authorities. The consequence has been that the legitimacy of different rules and regulations can always be disputed, contested, and evaded, opening easy opportunities for those who wish to contravene previously accepted regulations (Kepe and Scoones, 1999). The local use of fire is, therefore, subject to these institutional dynamics, which benefit some, while at the same time are to the detriment of others.

To conclude, this paper argues that while there are clearly justifiable reasons for being concerned about the ecological effects of fire in rangelands used by poor people, the solutions may lie somewhere else. Detailed understanding of the nature of livelihoods, the history and aspirations of the people concerned, as well as local institutional landscape is crucial. In other words environmental degradation, whether by fire or other things, is not an ecological issue alone, it is as deep as the people's histories, economic and political situation and, therefore, has to be dealt with and understood in that context.

\section{Acknowledgements}

An earlier version of this paper was presented at an international conference "The Eastern Cape: Historical Legacies and New Challenges", East London, 27-30 August 2003. I am grateful to NORAD (Norway) and Human Sciences Research Council (HSRC), South Africa, for financial support that allowed me to do fieldwork.

\section{End notes}

${ }^{1}$ See Proclamation No.270 of 1933 (Preservation of Thatch Grass and Rushes in the Transkeian Territories).

${ }^{2}$ Section 10 of National Veld and Forest Fire Act

(No.101, 1998).

3Proclamation No.141 of 1910 and Proclamation 270 of 1933

\section{REFERENCES}

Acocks, J.P.H., 1953: Veld Types of South Africa. Memoirs Botanical Survey of South Africa 28, Department of Agriculture, Pretoria.

Barlow, M and Buchan, B., 1995: The Last of the Lotus Lands: Being an Account of Twenty-four Years Spent in Pondoland, Kohler Carton \& Print, Durban.

Batterbury, S., T. Forsyth and K. Thomson., 1997: Environmental transformations in developing countries: hybrid research and democratic policy, The Geographical Journal, 163, (2), 126-132.

Beinart, W., 1982: The Political Economy of Pondoland 1860 to 1930, Ravan Press, Johannesburg.

Beinart, W., 1989: Introduction: The politics of colonial conservation, Journal of Southern African Studies, 15(2),143162.

Beinart, W., 1992: Transkeian smallholders and agrarian reform, Journal of Contemporary African Studies, 11(2), 178-199.

Beinart, W., 2002: Environmental origins of the Pondo revolt. In: Dovers, S; Edgecombe, R \& Guest, B (eds). South Africa's Environemental History. Cases \& Comparisons, David Phillip, Cape Town.

Beinart, W. and Bundy, C., 1987: Hidden Struggles in Rural South Africa: Politics and Popular Movements in the Transkei and Eastern Cape 1890-1930, Raven Press, Johannesburg.

Benjaminsen, T.A and Derman, B., 2003: Political ecology: understanding policies, conflicts and power in environmental governance. A research proposal, noragric, agricultural University of Norway.

Bijker, H.J., Sumner, P.D., Meiklejohn, K.I and Bredenkamp, G.J., 2001: Documenting the effects of veld burning on the soil and vegetation characteristics in Giant's Castle Game Reserve, KwaZulu-Natal Drakensberg, South African Geographical Journal, 83(1), 28-33.

Blaikie, P., 1985: The Political Economy of Soil Erosion in Developing Countries, Longman, London.

Botha, C.G., 1924: Note on early veld burning in the Cape Colony, South African Journal of Science, 21, 351-352. 
Booysen, P.deV. and Tainton, N.M., (Eds) 1984: Ecological Effects of Fire in South African Ecosystems, SpringerVerlag, Berlin.

Briers, J.H., M. Powell., J.M. Feely and P.M. Norton., 1996: Identification and Preliminary Evaluation of Potential Conservation Areas Along the Pondoland Coast, Ministry of Economic Affairs, Environment and Tourism, Directorate of Nature Conservation, Port Elizabeth.

Bryant, R.L, and Bailey, S., 1997: Third World Political Ecology, Routledge, London.

Bucini, G and Lambin, E.F., 2002: Fire impacts on vegetation in central Africa: A Remote-sensing-based statistical analysis, Applied Geography, 22, 27-48.

Chambers, R. and G. Conway., 1992: Sustainable Rural Livelihoods: Practical Concepts for the 21st Century, IDS Discussion Paper No. 296, Institute of Development Studies, Brighton.

Cooper, K., 1991: The Transkei Wild Coast, Veld \& Flora, 77(4), 108-110.

Copelyn, J.A., 1974: The Mpondo Revolt 1960, Bachelor of Arts Honours Thesis, University of Witwatersrand, Johannesburg.

De Wet, C., 1995: Moving Together, Drifting Apart: The Dynamics of Villagisation in a South African Homeland, Witwatersrand University Press, Johannesburg.

Ellery, W.N. and Mentis, M.T., 1992: How old are South Africa's grasslands? In: Furley, P., Proctor, J and Ratter, J (eds), Nature and Dynamics of Forest-Savanna Boundaries, Chapman and Hall, Johannesburg.

Feely, J.M., 1987: The Early farmers of Transkei, Southern Africa, Before A.D. 1870. Cambridge monographs in African archaeology No 24, BAR International Series No. 378, Cambridge.

Henkel, C.C., 1903: History, Resources and Productions of the Country Between Cape Colony and Natal, or Kaffraria Proper, Now Called the Native or Transkeian Territories, Hamburg Press, Hamburg.

Hershkovitz, L., 1993: Political ecology and environmental management in the Loess Plateau, China, Human Ecology, 21(4), 327-353.

Hunter, M., 1979: Reaction to Conquest: Effects of Contact with Europeans on the Pondo of South Africa, Abridged Edition, David Philip, Cape Town.

Fairhead, J and Leach, M., 1996: Misreading the African Landscape: Society and Ecology in a Forest-savanna Mosaic, Cambridge University Press, Cambridge.

Kepe, T., 2001: Waking Up from the Dream: The Pitfalls of "fast-track" Development on the Wild Coast of South Africa, Research Report No. 8. Programme for land and Agrarian Studies, University of the Western Cape, Bellville.

Kepe, T., 2002: The dynamics of cattle production and government intervention in communal areas of Lusikisiki District. In: Ainslie, A. (ed), Cattle Ownership and
Production in the Communal Areas of the Eastern Cape, South Africa, Programme for Land and Agrarian Studies, University of the Western Cape, Bellville.

Kepe, T. and Scoones, I., 1999: Creating grasslands: social institutions and environmental change in Mkambati area, South Africa, Human Ecology, 27(1), 29-53.

Kuhlken, R., 1999: Settin' the woods on fire: rural incendiarism as protest. Geographical Review, 89(3), 343-363.

Kull, C.A., 2002: Madagascar aflame: landscape burning as peasant protest, resistance, or resource management tool? Political Geography, 21, 927-953.

Kuckertz, H., 1990: Creating Order: The Image of the Homestead in Mpondo Social Life, Witwatersrand University Press, Johannesburg.

Laris, P., 2002: Burning the seasonal mosaic: preventative burning strategies in the wooded savanna of southern Mali, Human Ecology, 30(2), 155-186.

Leach, M. and Mearns, R., (Eds) 1996: The Lie of the Land: Challenging Received Wisdom on the African Environment, James Curry, Oxford.

Mabogunje, A.L., 2002: Poverty and environmental degradation, Environment, 44(1), 8-18.

Maloka, T., 1996: Populism and politics of chieftaincy and nation-building in the new South Africa, Journal of Contemporary African Studies, 14(2), 173-196.

Marloth, R., 1924: Notes on the question of veld burning, South African Journal of Science, 21, 342-345.

Mbeki, G., 1984: South Africa: The Peasants Revolt, International Defence Aid Fund, London.

Ntsebeza, L., 1999: Democratization and traditional authorities in the new South Africa, Comparative Studies of South Asia, Africa and the Middle East, XIX (1), 84-94.

Perestrello, M., [1554] 1898: Narrative of the wreck of ship San Bento. In: Theal, G. (ed.). Records of Southern-eastern Africa (Vol 1), Government of the Cape Colony, Cape Town.

Sampson, V., 1882: A trip through Pondoland to the mouth of St. Johns River, Cape Quarterly Review, 5(2), 100-119.

Sanderson, S.E and Redford, K.H., 2003: Contested relationships between biodiversity conservation and poverty alleviation, Oryx, 37(4), 1-2.

Scoones, I., 1996: Politics, polemics \& pasture in southern Africa. In: Leach, M. and Mearns, R. (eds), The Lie of the Land: Challenging Received Wisdom on the African Environment, James Curry, Oxford.

Schmidt, M and Doonan, C., 1997: Uproar over wild coast deal, Sunday Times, October 05.

Scott, J.C., 1985: Weapons of the Weak: Everyday Forms of Peasant Resistance, Yale University Press, New Haven.

Shackleton, S.E., 1990: Socio-economic importance of Cymbopogon validus in Mkambati Game Reserve, Transkei, 
South African Journal of Botany, 56(6), 675-682.

Slater, R., 2001: De-industrialisation, multiple livelihoods and identity: tracking social change in Qwaqwa, South Africa, Journal of Contemporary African Studies, 19(1), 81-92.

Stapleton, T.J., 2001: Faku. Rulership and Colonialism in the Mpondo Kingdom 1780 - 1867, Wilfred Laurier University Press, Waterloo.

Tiffen, M., Mortimore, M. and Gichuki, F., 1994: More People, Less Erosion: Environmental Recovery in Kenya, Wiley, Chichester.

Roe, E., 1991: Development narratives, or making the best of blueprint development, World Development, 19(4), 287300.

Russell, B., 2003: Stop the fires and improve your veld. An interview with Dr Nelis Moll, Farmer's Weekly, March 28.

Van Wyk, A.E., 1994: Maputaland-pondoland region: South Africa, Swaziland and Mozambique. In: Davies, S.D., Heywood, V.H. and Hamilton, A.C. (eds), Centres of Plant Diversity: A Guide and Strategy for their Conservation, Volume 1. IUCN Publications, Cambridge.
Venter, A.D., 1968: The Problems of Aristida junciformis encroachment into the veld of Natal, Proceedings of Grassland Society of Southern Africa, 3, 163-165.

Wiseman, R., Morris, C.D. and Granger, J.E., 2002: Effects of pre-planting treatments on the initial establishment success of indigenous grass seedlings planted into a degraded Aristida junciformis-dominated grassland, South African Journal of Botany, 68, 362-369.

T. Kepe Programme for Land and Agrarian Studies, School of Government University of the Western Cape, Private Bag X17, Bellville, 7535, South Africa Email:tkepe@uwc.ac.za 